\title{
Methyl isocyanide as a convertible functional group for the synthesis of spirocyclic oxindole Y-lactams via post-Ugi-4CR/transamidation/cyclization in a one-pot, three-step sequence
}

\author{
Amarendar Reddy Maddirala and Peter R. Andreana*
}

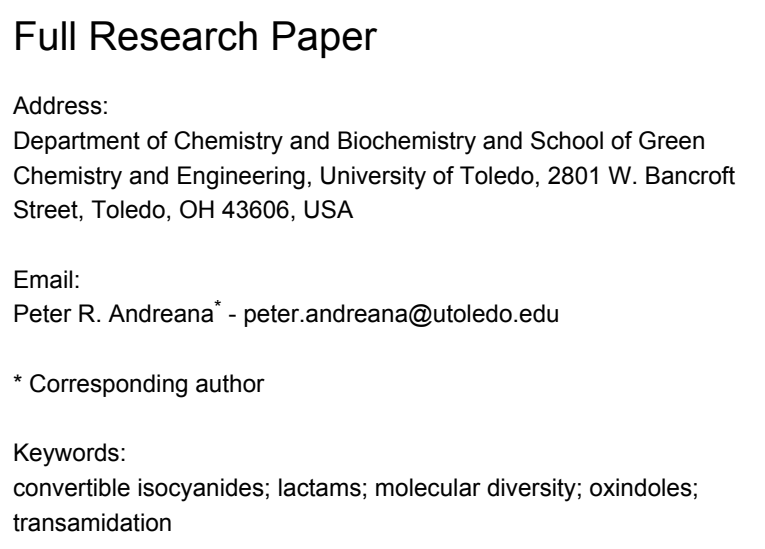

Beilstein J. Org. Chem. 2018, 14, 875-883. doi:10.3762/bjoc. 14.74

Received: 16 December 2017

Accepted: 27 March 2018

Published: 18 April 2018

Associate Editor: T. J. J. Müller

(c) 2018 Maddirala and Andreana; licensee Beilstein-Institut. License and terms: see end of document.

\begin{abstract}
The synthesis of spiro[indoline-3,2'-pyrrole]-2,5'(1'H)-diones and spiro[indoline-3,2'-pyrrolidine]-2,5'-diones, via a post-Ugidomino transamidation/cyclization sequential process, has been achieved in three sequential steps utilizing a one-pot reaction protocol. The variation in carboxylic acid substrates allows for the generation of new chiral racemic quaternary carbon centers under basic conditions providing molecular diversity and a small library of spirocyclic oxindoles.
\end{abstract}

\section{Introduction}

The Ugi-multicomponent coupling reaction [1,2], followed by post-modification transformations involving tandem reaction sequences [3] and the Ugi-deprotection-cyclization (UDC) strategies [4-8] have been exploited as powerful tools allowing access to biological and pharmaceutical high-value heterocyclic scaffolds [9-11]. These reactions are appealing in that they are atom economical, simple and generate ample molecular diversity with the ease of using readily available starting materials. Developing new, post-modified Ugi-four-component reaction (Ugi-4CR) transformations in domino cyclization [12-15] se- quences are very important for achieving unprecedented chemical bonds and functionality towards the construction of synthetic scaffolds.

The synthesis of spirocyclic oxindoles has always been of key interest to organic chemists because of significant biological activity [16-20] and their presence in naturally occurring molecules [21-23]. Significant efforts have been made to design creative synthetic strategies for spirocyclic oxindole molecules, of which, isatin-based domino reactions [24-30] have proved to 
be very versatile [31] and readily achievable [32-37]. However, finding a simple and efficient synthetic method for these molecules that allows for structural diversity is also important but not necessarily trivial. For these and other reasons, we became interested in synthesizing spiro[indoline-3,2'-pyrrole]-2,5'(1'H)dione and spiro[indoline-3,2'-pyrrolidine]-2,5'-dione scaffolds (a class of spirocyclic oxindole $\gamma$-lactams).

There have been other groups in the past, including our own research group, who have reported on post-modified Ugi-fourcomponent synthetic strategies (Scheme 1) towards the synthesis of 2-oxindoles and spiro[indoline-3,2'-pyrrole]-2,5'(1'H)diones and spiro[indoline-3,2'-pyrrolidine]-2,5'-diones. Zhu et al. [38] reported 3-substituted-2-indolinones via a microwaveassisted post-Ugi-4CR/Buchwald-Hartwig reaction and another similar approach was illustrated by Van der Eycken et al. [39] for spiro[indoline-3,2'-pyrrole]-2,5'(1'H)-diones. In previous efforts to study 3 -substituted 2-indolinones through a three-step post-Ugi-4CR/Bechamp type-reduction followed by a transamidation sequence strategy [40], we came across interesting observations. We noted that when methyl isocyanide $[41,42]$ was used for the Ugi-4CR and the subsequent post-intramolecular transamidation was performed under acidic conditions, particularly in the presence of TFA, the reaction led to 3-substituted 2 -indolinones in a three-step process [40]. In this work, we discovered that methyl isocyanide [43] operates under a mecha- nism of convertible isocyanides (CICs) [44-49], and could be thought of as a synthetic equivalent to ' $\mathrm{CO}$ ' for insertion into the 2-indolinone backbone (shown in Scheme 1). To further elaborate on this observation and for understanding the role of methyl isocyanide as a CIC, we designed an efficient synthetic strategy for spiro[indoline-3,2'-pyrrole]-2,5'(1'H)-diones and spiro[indoline-3,2'-pyrrolidine]-2,5'-diones via a one-pot, threestep reaction sequence. Advantages of this strategy include: a) minimal number of synthetic steps, b) avoidance of tedious work-up procedures including purification, and c) use of starting materials either readily available or facile to synthesize.

Here within, we document that the reaction sequence for spirocyclic oxindole $\gamma$-lactams (Scheme 2) follows a three-step sequential strategy involving: a) an Ugi-4CR, b) an acidpromoted intramolecular transamidation, and c) a base-mediated cyclization giving spiro[indoline-3,2'-pyrrole]-2,5'(1'H)diones. We propose that the acid-mediated Boc deprotection in the Ugi intermediate $\mathbf{5}$ leads to aniline intermediate $\mathbf{I}$ which can simultaneously undergo a CIC cyclization through an intramolecular transamidation process giving compound $\mathbf{6}$ and, in the process, extrude methylamine as a gaseous byproduct. Furthermore, compound 6 is proposed to undergo an intramolecular cyclization, under basic conditions, yielding target compounds 7 (Scheme 2).

Zhu et al. post-Ugi-4-CR/Buchwald-Hartwig reaction sequence<smiles>[R][R]1ccc2c(c1)C(N([R])C([R])=O)C(=O)N2[R]</smiles>

Van der Eycken et al. post-Ugi-4-CR/Buchwald-Hartwig/Michael addition sequence<smiles></smiles>

our previous work. post-Ugi-4-CR/Bechamp/transamidation sequence

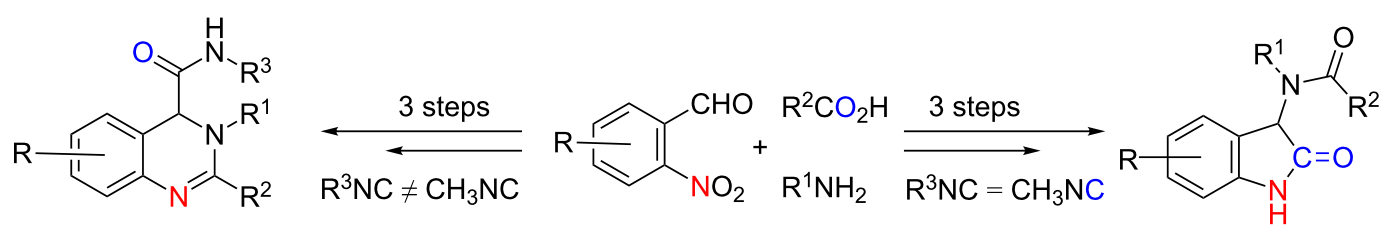




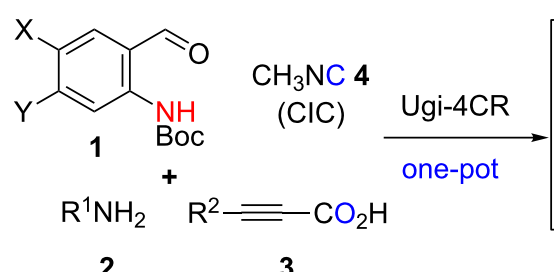<smiles>[R]C#CC(=O)N([R1])C(C(=O)NC)c1cc([X])c([Y])cc1NC</smiles><smiles>[R]C#CC(=O)N([R])C(NC)c1cc(C)c([Y])cc1NC</smiles>

$\mathrm{X}=\mathrm{Y}=\mathrm{H}, \mathrm{OMe},-\mathrm{OCH}_{2} \mathrm{O}-$

$\mathrm{X}=\mathrm{OMe}, \mathrm{Y}=\mathrm{H}$

$\mathrm{X}=\mathrm{Cl}, \mathrm{Y}=\mathrm{H}$

$\mathrm{X}=\mathrm{H}, \mathrm{Y}=\mathrm{CF}_{3}$

$\mathrm{R}^{1}=$ alkyl or aryl

$\mathrm{R}^{2}=\mathrm{CH}_{3}, \mathrm{C}_{2} \mathrm{H}_{5}, \mathrm{C}_{3} \mathrm{H}_{7}$<smiles>[R]C1=CC(=O)N([R])C12C(=O)Nc1cc([X])c([Y])cc12</smiles><smiles>[R]CC1(CC)C(=O)Nc2cc([X])c([X])cc21</smiles>

Scheme 2: Post-Ugi-4CR/transamidation/cyclization sequence.

\section{Results and Discussion}

Our initial synthetic attempts began with the Ugi-4CR involving stoichiometrically equal amounts of 2-(Boc-amino)benzaldehyde (1a), aniline (2a), tetrolic acid (3a), and methyl isocyanide (4) in methanol at room temperature to generate adduct 5a; confirmed using mass spectroscopic analysis (Scheme 3). Intermediate 5a, which was not purified, was prone to undergo an intramolecular transamidation when 50\% TFA was used to remove the Boc group in DCM at room temperature for $5 \mathrm{~h}$ ultimately yielding $\mathbf{6 a}$ and methylamine as the gaseous byproduct. Following the neutralization of TFA, unpurified compound $\mathbf{6 a}$ was tested for the ability to cyclize under basic conditions. We began our cyclization studies with $\mathbf{6 a}$ by dissolving it in acetonitrile following by the addition of 2 equiv $\mathrm{K}_{2} \mathrm{CO}_{3}$ and then refluxing for $1 \mathrm{~h}$. The reaction was monitored by TLC, which indicated the disappearance of the starting material and formation of a new spot. Post-work-up and purification, spectroscopic analysis of the product matched nicely with the 5-endo-dig cyclization product 7a and not the 4-exo-dig-cyclization compound $\mathbf{7} \mathbf{a}^{\prime}$ (Scheme 3 ). We rationalized, as per Baldwin's rules, that the 5-endo-dig cyclization of a 1,4Michael addition was more favorable than the 4-exo-dig-cyclization [50,51]. The structure of compound 7a was definitively confirmed by X-ray analysis (Figure 1).<smiles>CC(C)(C)OC(=O)Nc1ccccc1C=O</smiles>

$1 \mathrm{a}$

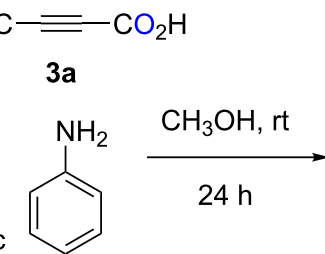

2a<smiles>CC#CC(=O)N(c1ccccc1)C(C(=O)NC)c1ccccc1C(=O)O</smiles>

$5 a$

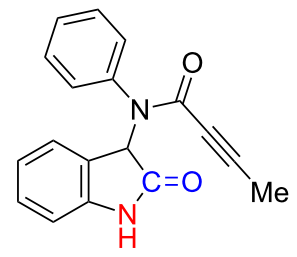

$6 a$

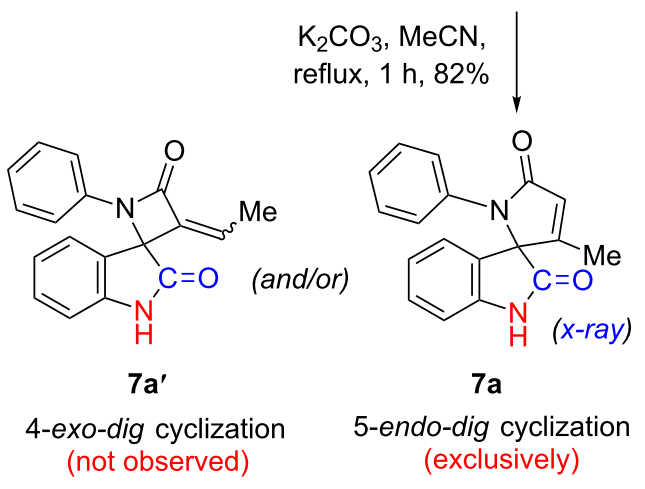




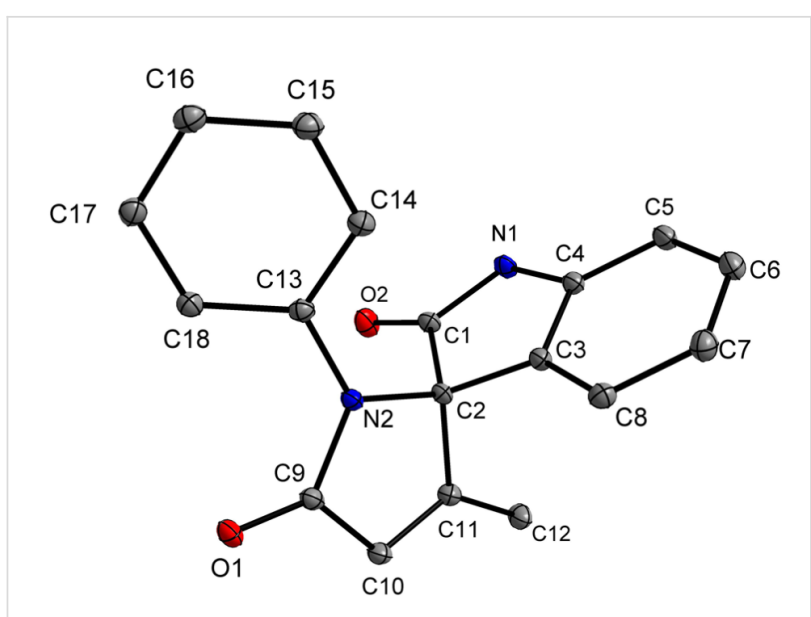

Figure 1: ORTEP diagram of compound $7 \mathbf{a}$.

We then elected to carry out yield optimization studies of the cyclization reaction using a number of solvents, reagents and reaction temperatures (Table 1) and also to explore the possibility of a possible 4-exo-dig outcome. The study validated that all the reaction conditions, with the exception of AgOTf/DCM (Table 1, entry 6), led to the formation of the desired 5-endo-dig cyclization product $7 \mathbf{a}$ and none of the 4-exo-dig cyclization product 7a' was observed. In Table 1, entries $2-5$ and 7 show moderate product yields whereas entries 1 and 8 show superior yields of $>80 \%$.

With the optimized reaction conditions in hand (Table 1, entries 1 and 8), the substrate scope was explored using a one-pot Ugi$4 \mathrm{CR} /$ transamidation/cyclization sequence employing various combinations of readily available and synthetically accessible starting materials (Figure 2). Under all circumstances, the intramolecular cyclization proceeded smoothly using $\mathrm{K}_{2} \mathrm{CO}_{3} / \mathrm{MeCN}$ reflux conditions and products $\mathbf{7} \mathbf{b}-\mathbf{k}$ were obtained in good to excellent yields (Scheme 4). Although the results shown only reflect the use of $\mathrm{K}_{2} \mathrm{CO}_{3} / \mathrm{MeCN}$ reflux conditions, similar, if not exact reaction outcomes were observed when conditions from Table 1 , entry 8 were used.

To further explore the utility of our methodology, we examined similar reaction conditions for the synthesis of spiro[indoline3,2'-pyrrolidine]-2,5'-dione scaffolds (Scheme 5). For this reaction we used 2-(Boc-amino)benzaldehyde 1c, aniline (2a), 3-chloropropanoic acid (3e) and methyl isocyanide (4) in a onepot reaction process to generate compound $\mathbf{6 b}$ from $\mathbf{5 b}$. In all cases, the Michael acceptor [52] (intermediate II) was generated in situ from $\mathbf{6 b}$, under basic conditions (Table 1, entry 1 , $\mathrm{K}_{2} \mathrm{CO}_{3} / \mathrm{MeCN} /$ reflux), followed by the intramolecular cyclization proceeding through a 1,4-Michael addition to form an exclusive 5-endo-trig cyclization of 5-chloro-1'-phenylspiro[indoline-3,2'-pyrrolidine]-2,5'-dione (8a, Scheme 5). Compound 8a was unequivocally confirmed by both, mass spectral analysis and NMR.

Encouraged by the results, we prepared a library of spiro[indoline-3,2'-pyrrolidine]-2,5'-diones $\mathbf{8 b}$-i from readily available starting materials in which overall yields were determined to be moderate to good (Figure 3). Furthermore, the applicability and utility of this process was demonstrated through the synthesis of a 5-HT6 receptor antagonist $\mathbf{8 j}$ (Scheme 6) [53].

\section{Conclusion}

In conclusion, we have investigated and developed an efficient process towards spirocyclic $\alpha, \beta$-unsaturated $\gamma$-lactam oxindoles and spirocyclic $\gamma$-lactams using a one-pot three-step post-Ugi$4 \mathrm{CR}$ intramolecular transamidation/cyclization approach. We utilized this strategy for the synthesis of a small library of spiro[indoline-3,2'-pyrrole]-2,5'(1'H)-dione and spiro[indoline3,2'-pyrrolidine]-2,5'-dione analogs illustrating important utility toward biologically relevant compounds. To this point, our strategy was further extended and applied towards the synthesis of a well-known 5-HT6 receptor antagonist 8j. We also successfully utilized methyl isocyanide, as a CIC, for spiro[indoline-

\begin{tabular}{|c|c|c|c|c|c|c|}
\hline entry & reagent & solvent & temperature & time & yield 7a (\%) & yield 7a' (\%) \\
\hline 1 & $\mathrm{~K}_{2} \mathrm{CO}_{3}$ & MeCN & reflux & $1 \mathrm{~h}$ & 82 & n.o. \\
\hline 2 & $\mathrm{~K}_{2} \mathrm{CO}_{3}$ & methanol & $\mathrm{rt}$ & $2 \mathrm{~h}$ & 72 & n.o. \\
\hline 3 & $\mathrm{~K}_{2} \mathrm{CO}_{3}$ & toluene & reflux & $2 \mathrm{~h}$ & 70 & n.o. \\
\hline 4 & $\mathrm{Cs}_{2} \mathrm{CO}_{3}$ & toluene & reflux & $2 \mathrm{~h}$ & 72 & n.o. \\
\hline 5 & $\mathrm{Et}_{3} \mathrm{~N}$ & DCM & $\mathrm{rt}$ & $4 \mathrm{~h}$ & 65 & n.o. \\
\hline 6 & AgOTf & DCM & $\mathrm{rt}$ & $24 \mathrm{~h}$ & n.r. & n.r. \\
\hline 7 & $\mathrm{KO} t-\mathrm{Bu}$ & THF & $\mathrm{rt}$ & $30 \min$ & 75 & n.o. \\
\hline 8 & $\mathrm{KOt-Bu}$ & MeCN & rt & $30 \mathrm{~min}$ & 80 & n.o. \\
\hline
\end{tabular}

${ }^{a}$ n.o.: not observed, n.r.: no reaction; highlighted entries denote best results. 
aldehydes: 1a-f

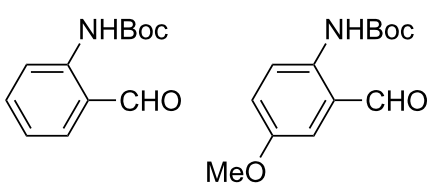

$1 \mathrm{~b}$

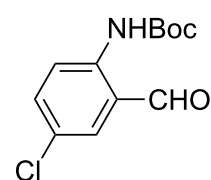

1c

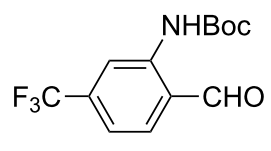

$1 \mathrm{~d}$

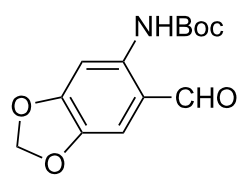

$1 \mathrm{e}$

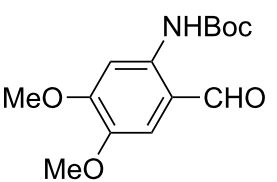

$1 f$

amines $\left(\mathrm{R}^{1} \mathrm{NH}_{2}\right)$ : $2 \mathrm{a}-\mathrm{p}$

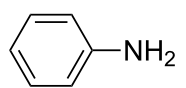

$2 a$<smiles>Nc1ccc([N+](=O)[O-])cc1</smiles>

$2 b$<smiles>COc1ccc(N)cc1</smiles>

2c<smiles>Nc1ccc(Br)cc1</smiles>

2d<smiles>NC1CC1</smiles>

$2 \mathrm{e}$<smiles>CC(C)N</smiles>

$2 f$

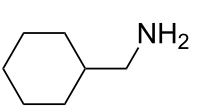<smiles>COc1cccc(CN)c1</smiles>

$2 \mathrm{~g}$<smiles>NCc1ccccc1</smiles>

$2 h$

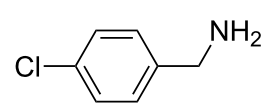

2i<smiles>NCc1ccccc1Br</smiles>

2j<smiles>NC1CCCC1</smiles>

2k

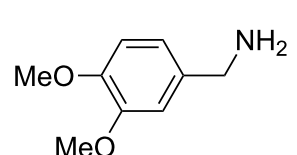

$2 \mathrm{~m}$

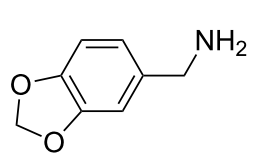

2n

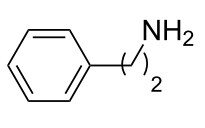

20

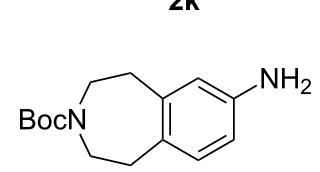

$2 p$

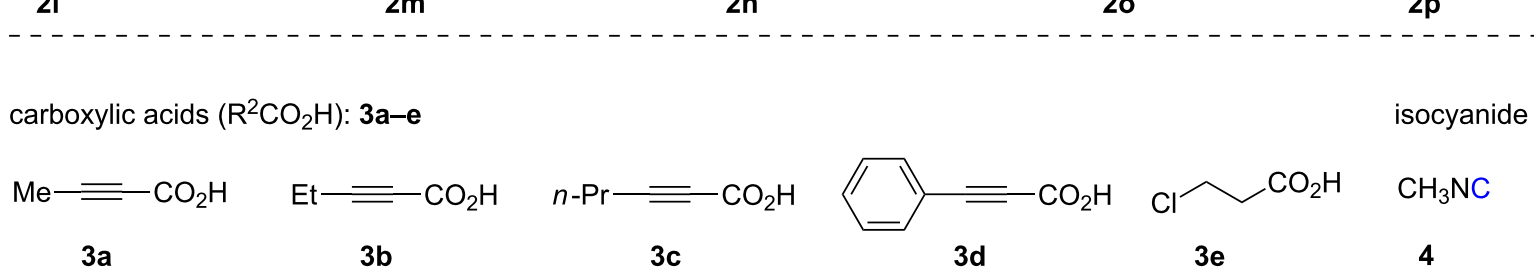

Figure 2: Readily and synthetically accessible starting materials.

3,2'-pyrrole]-2,5'(1'H)-diones and spiro[indoline-3,2'-pyrrolidine]-2,5'-diones. Immediate plans are underway to test the inhibitory properties of the newly synthesized compounds in in vitro assays.

\section{Experimental}

All reagents and solvents that were purchased were used without further purification unless otherwise stated. Reaction progress was monitored by thin-layer chromatography (TLC). Spots on TLC were visualized using UV light. Column chromatography was performed using normal-phase silica gel. Yields refer to chromatographically and spectroscopically pure compounds. ${ }^{1} \mathrm{H}$ and ${ }^{13} \mathrm{C}$ NMR were recorded using a Bruker Avance III $600 \mathrm{MHz}$. The residual DMSO- $d_{6}{ }^{1} \mathrm{H}$ quintet at $\delta 2.50 \mathrm{ppm}$ and residual ${ }^{13} \mathrm{C}$ septet at $\delta 39.51 \mathrm{ppm}, \mathrm{CDCl}_{3}$ ${ }^{1} \mathrm{H}$ singlet at $\delta 7.27 \mathrm{ppm}$ and ${ }^{13} \mathrm{C}$ triplet at $\delta 77.23 \mathrm{ppm}$ were used as standards for ${ }^{1} \mathrm{H}$ NMR and ${ }^{13} \mathrm{C}$ NMR spectra, respectively. Signal patterns are indicated as s: singlet; d: doublet; t: triplet; q: quartet; m: multiplet; dd: doublet of doublets; and br: broad. Coupling constants are reported in hertz $(\mathrm{Hz})$. High resolution mass spectra (HRMS) were obtained using a Bruker Maxis 4G mass spectrometer.

General procedure for $7 \mathbf{a}-\mathbf{k}$ : Into a clear solution of 2-(Bocamino)benzaldehyde $\mathbf{1}$ (1 mmol) in methanol $(5 \mathrm{~mL})$ was added amine $2(1 \mathrm{mmol})$ and stirred for 5 minutes at room temperature. Carboxylic acid 3 (1 mmol) and methyl isocyanide (4, $1 \mathrm{mmol})$ were then added simultaneously. The mixture was stirred until no noticeable amounts of starting material were visible by TLC. Upon completion of the reaction, methanol was evaporated under reduced pressure and the crude Ugi products, without any purification, dissolved in a $\mathrm{CH}_{2} \mathrm{Cl}_{2}$ and trifluoroacetic acid mixture $(1: 1,2 \mathrm{~mL})$ and subsequently stirred at room temperature for $5 \mathrm{~h}$. The reaction progress was monitored by TLC and upon completion of the reaction the solvent was evaporated under reduced pressure. Without any purification, the 

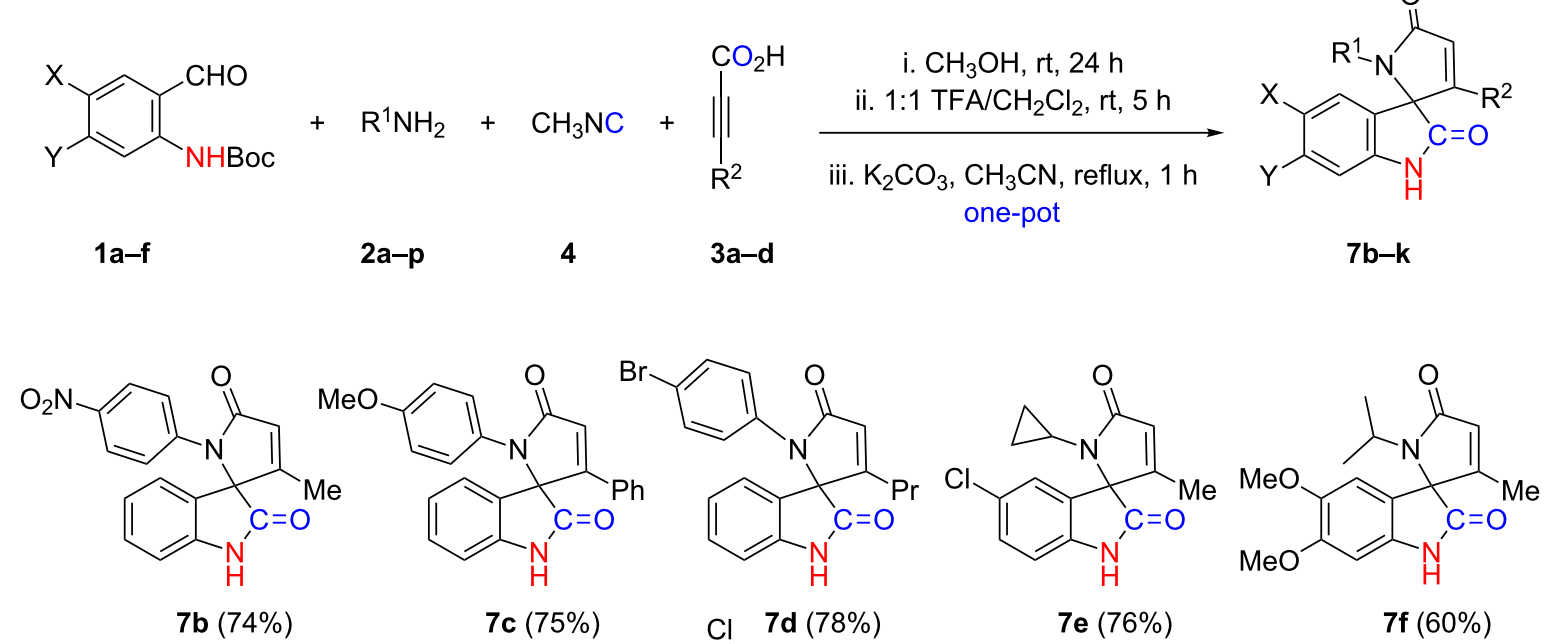<smiles>CCC1=CC(=O)N(Cc2cccc(OC)c2)C12C(=O)Nc1ccc([18O])cc12</smiles><smiles>CCC1=CC(=O)N(Cc2ccc(C)cc2)C12C(=O)Nc1ccccc12</smiles><smiles>CCC1=CC(=O)N(C(C)C)C12C(=O)Nc1cc3c(cc12)OCO3</smiles><smiles>O=C1C=C(c2ccccc2)C2(C(=O)Nc3ccccc32)N1Cc1ccccc1Br</smiles>

Scheme 4: Reaction scope with varying combinations of substrates.

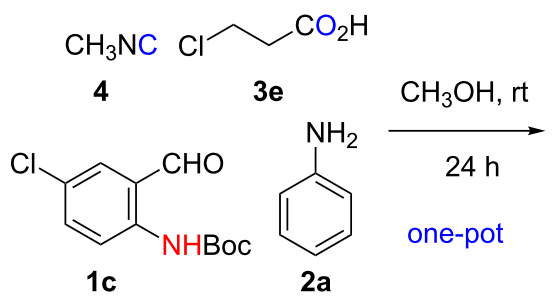<smiles>CNC(=O)c1ccc(Cl)cc1C(C(=O)Nc1ccccc1)N(C(=O)CCl)c1ccccc1</smiles>

$5 b$

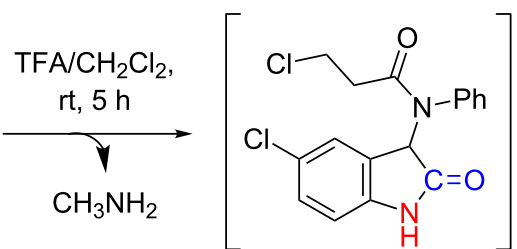

$6 \mathrm{~b}$

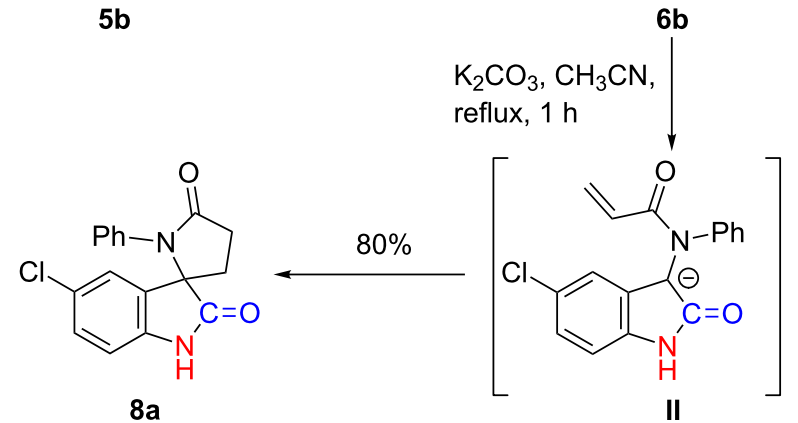

Scheme 5: Synthesis of 5-chloro-1'-phenylspiro[indoline-3,2'-pyrrolidine]-2,5'-dione (8a).

crude compound was dissolved in acetonitrile $(2 \mathrm{~mL})$ and $\mathrm{K}_{2} \mathrm{CO}_{3}(2 \mathrm{mmol})$ was added. The reaction was allowed to stir under refluxing conditions for $1 \mathrm{~h}$ and the reaction was monitored for completion using TLC. Upon noted completion of the reaction, the mixture was cooled to room temperature and the solvent was evaporated under reduced pressure. The crude compound(s) was subjected to flash column chromatography (EtOAc/hexanes) to yield pure compounds $7 \mathbf{a}-\mathbf{k}$. 
<smiles>O=C1CCC2(C(=O)Nc3ccccc32)N1C1CCCC1</smiles>

$\mathbf{8 b}(81 \%)$<smiles>O=C1CCC2(C(=O)Nc3ccccc32)N1Cc1ccc2c(c1)OCO2</smiles>

$8 f(77 \%)$

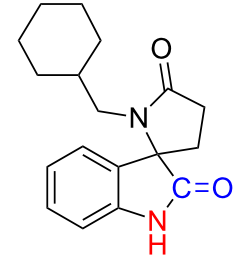

$8 c(79 \%)$<smiles>O=C1CCC2(C(=O)Nc3ccccc32)N1CCc1ccccc1</smiles>

$8 g(80 \%)$<smiles>COc1ccc2c(c1)C1(CCC(=O)N1Cc1ccccc1)C(=O)N2</smiles>

$8 d(79 \%)$<smiles>O=C1CCC2(CCC(=O)N2Cc2ccccc2Br)c2ccccc21</smiles>

8 h $(82 \%)$<smiles>COc1ccc(CN2C(=O)CCC23C(=O)Nc2ccc(Cl)cc23)cc1OC</smiles>

$8 \mathbf{e}(80 \%)$<smiles>COc1cc2c(cc1OC)C1(CCC(=O)N1C(C)C)C(=O)N2</smiles>

$8 \mathbf{i}(62 \%)$

Figure 3: Small molecule library of spiro[indoline-3,2'-pyrrolidine]-2,5'-dione analogs.<smiles>CC(C)(C)OC(=O)N1CCc2ccc(N)cc2CC1</smiles>

$2 p$<smiles>O=C(O)CCCl</smiles>

$3 e$<smiles>Nc1ccccc1C=O</smiles>

$1 \mathrm{a}$

Boc

$\mathrm{CH}_{3} \mathrm{NC}$

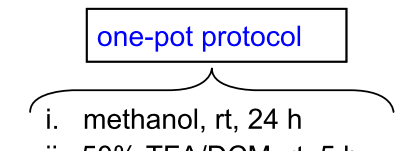

ii. $50 \%$ TFA/DCM, rt, $5 \mathrm{~h}$

iii. $\mathrm{K}_{2} \mathrm{CO}_{3}, \mathrm{CH}_{3} \mathrm{CN}$, reflux, $1 \mathrm{~h}$

$65 \%$ yield over 3 steps<smiles>O=C1CCC2(C(=O)Nc3ccccc32)N1c1ccc2c(c1)CCNCC2</smiles>

8j

Scheme 6: Method applicability for the one-pot synthesis of 5-HT6 receptor antagonist $8 \mathbf{j}$ [53].

General procedure for $8 \mathbf{a}-\mathbf{j}$ : Into a clear solution of 2-(Bocamino)benzaldehyde 1 ( $1 \mathrm{mmol})$ in methanol $(5 \mathrm{~mL})$ was added amine $2(1 \mathrm{mmol})$ and stirred for 5 minutes at room temperature. Then, 3-chloropropanoic acid (3,1 mmol) and methyl isocyanide $(4,1 \mathrm{mmol})$ were added to the reaction pot. The reaction was allowed to stir until no noticeable amounts of starting material were visible using TLC. Upon completion of the reaction, methanol was evaporated under reduced pressure and the crude Ugi products, without any purification, was dissolved in a $\mathrm{CH}_{2} \mathrm{Cl}_{2}$ and trifluoroacetic acid mixture $(1: 1,2 \mathrm{~mL})$. The reaction was then allowed to stir at room temperature for $5 \mathrm{~h}$ and monitored by TLC. Upon completion of the reaction, the solvent was evaporated under reduced pressure and the crude compound, without any purification, was dissolved in acetonitrile $(2 \mathrm{~mL})$ and $\mathrm{K}_{2} \mathrm{CO}_{3}(2 \mathrm{mmol})$ was added. The reaction was then allowed to stir under refluxing conditions for $1 \mathrm{~h}$ and reaction completion was monitored using TLC. The reaction mixture was then allowed to cool to room temperature and the solvent evaporated under reduced pressure. The crude products were subjected to flash column chromatography (EtOAc/hexanes) to yield pure compounds $\mathbf{8 a}-\mathbf{j}$.

\section{Supporting Information}

\section{Supporting Information File 1}

${ }^{1} \mathrm{H}$ and ${ }^{13} \mathrm{C}$ NMR spectroscopic data for compounds $7 \mathbf{a}-\mathbf{k}$ and $\mathbf{8 a}-\mathbf{j}$, and X-ray crystal structure details for $\mathbf{7 a}$. [https://www.beilstein-journals.org/bjoc/content/ supplementary/1860-5397-14-74-S1.pdf]

\section{Acknowledgements}

This work was supported by The University of Toledo. We would like to acknowledge Dr. Kristin Kirschbaum and Jennifer Gadient for providing X-ray crystal structure data. 


\section{ORCID ${ }^{\circledR}$ iDs}

Amarendar Reddy Maddirala - https://orcid.org/0000-0003-0721-1647

\section{References}

1. Ugi, I.; Steinbrückner, C. Angew. Chem. 1960, 72, 267-268. doi:10.1002/ange.19600720709

2. Dömling, A.; Ugi, I. Angew. Chem., Int. Ed. 2000, 39, 3168-3210. doi:10.1002/1521-3773(20000915)39:18<3168::AID-ANIE3168>3.0.CO ;2-U

3. Sharma, U. K.; Sharma, N.; Vachhani, D. D.; Van der Eycken, E. V. Chem. Soc. Rev. 2015, 44, 1836-1860. doi:10.1039/C4CS00253A

4. Hulme, C.; Peng, J.; Louridas, B.; Menard, P.; Krolikowski, P.; Kumar, N. V. Tetrahedron Lett. 1998, 39, 8047-8050. doi:10.1016/S0040-4039(98)01770-5

5. Huang, Y.; Khoury, K.; Chanas, T.; Dömling, A. Org. Lett. 2012, 14, 5916-5919. doi:10.1021/ol302837h

6. Xu, Z.; Shaw, A. Y.; Dietrich, J.; Cappelli, A. P.; Nichol, G.; Hulme, C. Mol. Diversity 2012, 16, 73-79. doi:10.1007/s11030-011-9354-x

7. Hulme, C.; Ma, L.; Romano, J.; Morrissette, M. Tetrahedron Lett. 1999, 40, 7925-7928. doi:10.1016/S0040-4039(99)01580-4

8. Hulme, C.; Ma, L.; Cherrier, M.-P.; Romano, J. J.; Morton, G.; Duquenne, C.; Salvino, J.; Labaudiniere, R. Tetrahedron Lett. 2000, 41, 1883-1887. doi:10.1016/S0040-4039(00)00052-6

9. Tempest, P.; Ma, V.; Thomas, S.; Hua, Z.; Kelly, M. G.; Hulme, C. Tetrahedron Lett. 2001, 42, 4959-4962. doi:10.1016/S0040-4039(01)00919-4

10. Dömling, A.; Wang, W.; Wang, K. Chem. Rev. 2012, 112, 3083-3135. doi:10.1021/cr100233r

11. Jiang, B.; Rajale, T.; Wever, W.; Tu, S.-J.; Li, G. Chem. - Asian J. 2010, 5, 2318-2335. doi:10.1002/asia.201000310

12. Bourgault, J. P.; Maddirala, A. R.; Andreana, P. R. Org. Biomol. Chem 2014, 12, 8125-8127. doi:10.1039/C4OB01148A

13. Koopmanschap, G.; Ruijter, E.; Orru, R. V. A. Beilstein J. Org. Chem. 2014, 10, 544-598. doi:10.3762/bjoc. 10.50

14. Santra, S.; Andreana, P. R. Angew. Chem., Int. Ed. 2011, 50, 9418-9422. doi:10.1002/anie.201103567

15. Santra, S.; Andreana, P. R. J. Org. Chem. 2011, 76, 2261-2264. doi:10.1021/jo102305q

16. De Silva, R. A.; Santra, S.; Andreana, P. R. Org. Lett. 2008, 10, 4541-4544. doi:10.1021/ol801841m

17. Kumar, A.; Gupta, G.; Bishnoi, A. K.; Saxena, R.; Saini, K. S.; Konwar, R.; Kumar, S.; Dwivedi, A. Bioorg. Med. Chem. 2015, 23 , 839-848. doi:10.1016/j.bmc.2014.12.037

18. Santos, M. M. M. Tetrahedron 2014, 70, 9735-9757. doi:10.1016/j.tet.2014.08.005

19. Yu, B.; Yu, D.-Q.; Liu, H.-M. Eur. J. Med. Chem. 2015, 97, 673-698. doi:10.1016/j.ejmech.2014.06.056

20. Yu, B.; Yu, Z.; Qi, P.-P.; Yu, D.-Q.; Liu, H.-M. Eur. J. Med. Chem. 2015, 95, 35-40. doi:10.1016/j.ejmech.2015.03.020

21. Dong, H.; Song, S.; Li, J.; Xu, C.; Zhang, H.; Ouyang, L. Bioorg. Med. Chem. Lett. 2015, 25, 3585-3591. doi:10.1016/j.bmcl.2015.06.076

22. Fu, P.; Kong, F.; Li, X.; Wang, Y.; Zhu, W. Org. Lett. 2014, 16, 3708-3711. doi:10.1021/ol501523d

23. Jossang, A.; Jossang, P.; Hadi, H. A.; Sevenet, T.; Bodo, B. J. Org. Chem. 1991, 56, 6527-6530. doi:10.1021/jo00023a016

24. Bacher, N.; Tiefenthaler, M.; Sturm, S.; Stuppner, H.; Ausserlechner, M. J.; Kofler, R.; Konwalinka, G. Br. J. Haematol. 2006, 132, 615-622. doi:10.1111/j.1365-2141.2005.05907.x
25. Singh, G. S.; Desta, Z. Y. Chem. Rev. 2012, 112, 6104-6155. doi:10.1021/cr300135y

26. Zhou, B.; Yang, Y.; Shi, J.; Luo, Z.; Li, Y. J. Org. Chem. 2013, 78, 2897-2907. doi:10.1021/jo302655u

27. Lv, H.; Tiwari, B.; Mo, J.; Xing, C.; Chi, Y. R. Org. Lett. 2012, 14, 5412-5415. doi:10.1021/ol302475g

28. Zhang, B.; Feng, P.; Sun, L.-H.; Cui, Y.; Ye, S.; Jiao, N. Chem. - Eur. J. 2012, 18, 9198-9203. doi:10.1002/chem.201201375

29. Dalpozzo, R.; Bartoli, G.; Bencivenni, G. Chem. Soc. Rev. 2012, 41, 7247-7290. doi:10.1039/c2cs35100e

30. Meloche, J. L.; Ashfeld, B. L. Angew. Chem., Int. Ed. 2017, 56, 6604-6608. doi:10.1002/anie.201701147

31. Zhu, G.; Liu, S.; Wu, S.; Peng, L.; Qu, J.; Wang, B. J. Org. Chem. 2017, 82, 4317-4327. doi:10.1021/acs.joc.7b00316

32. Wang, C.; Zhu, S.; Wang, G.; Li, Z.; Hui, X.-P. Eur. J. Org. Chem. 2016, 5653-5658. doi:10.1002/ejoc.201600958

33. Liu, Y.; Wang, H.; Wan, J. Asian J. Org. Chem. 2013, 2, 374-386. doi:10.1002/ajoc.201200180

34. Sun, Y.; Sun, J.; Yan, C.-G. Beilstein J. Org. Chem. 2013, 9, 8-14. doi:10.3762/bjoc.9.2

35. Miyamoto, H.; Hirano, T.; Okawa, Y.; Nakazaki, A.; Kobayashi, S. Tetrahedron 2013, 69, 9481-9493. doi:10.1016/j.tet.2013.08.057

36. Samineni, R.; Madapa, J.; Srihari, P.; Mehta, G. Org. Lett. 2017, 19, 3119-3122. doi:10.1021/acs.orglett.7b01233

37. Yang, P.; Wang, X.; Chen, F.; Zhang, Z.-B.; Chen, C.; Peng, L.; Wang, L.-X. J. Org. Chem. 2017, 82, 3908-3916. doi:10.1021/acs.joc.6b03090

38. Bonnaterre, F.; Bois-Choussy, M.; Zhu, J. Org. Lett. 2006, 8, 4351-4354. doi:10.1021/ol061755z

39. Sharma, N.; Li, Z.; Sharma, U. K.; Van der Eycken, E. Org. Lett. 2014, 16, 3884-3887. doi:10.1021/ol5019079

40. Maddirala, A. R.; Andreana, P. R. Eur. J. Org. Chem. 2016, 196-209. doi:10.1002/ejoc.201501273

41. Gautier, A. Justus Liebigs Ann. Chem. 1868, 146, 119-124. doi:10.1002/jlac.18681460107

42. Eckert, H.; Nestl, A.; Ugi, I. Methyl Isocyanide. Encyclopedia of Reagents for Organic Synthesis; John Wiley \& Sons, Ltd, 2001. doi:10.1002/047084289X.rm198

43. Schuster, R. E.; Scott, J. E.; Casanova, J., Jr. Org. Synth. 1966, 46, 75. doi:10.15227/orgsyn.046.0075

44. Santra, S.; Andreana, T.; Bourgault, J.-P.; Andreana, P. R. Convertible Isocyanides: Application in Small Molecule Synthesis, Carbohydrate Synthesis, and Drug Discovery. Domino and Intramolecular Rearrangement Reactions as Advanced Synthetic Methods in Glycoscience; John Wiley \& Sons, Inc., 2016; pp 121-194. doi:10.1002/9781119044222.ch7

45. Hulme, C.; Chappeta, S.; Dietrich, J. Tetrahedron Lett. 2009, 50, 4054-4057. doi:10.1016/j.tetlet.2009.04.095

46. Hulme, C.; Gore, V. Curr. Med. Chem. 2003, 10, 51-80. doi:10.2174/0929867033368600

47. Hulme, C.; Bienaymé, H.; Nixey, T.; Chenera, B.; Jones, W.; Tempest, P.; Smith, A. L. Library Generation via Postcondensation Modifications of Isocyanide-Based Multicomponent Reactions. Methods Enzymol.; Academic Press, 2003; Vol. 369, pp 469-496. doi:10.1016/S0076-6879(03)69024-5

48. Hulme, C.; Ayaz, M.; Martinez-Ariza, G.; Medda, F.; Shaw, A. Recent Advances in Multicomponent Reaction Chemistry. Small Molecule Medicinal Chemistry; John Wiley \& Sons, Inc: , 2015; pp 145-187. doi:10.1002/9781118771723.ch6 
49. Xu, Z.; De Moliner, F.; Cappelli, A. P.; Ayaz, M.; Hulme, C. Synlett 2014, 25, 225-228. doi:10.1055/s-0033-1340219

50. Alabugin, I. V.; Gilmore, K.; Manoharan, M. J. Am. Chem. Soc. 2011, 133, 12608-12623. doi:10.1021/ja203191f

51. Gilmore, K.; Alabugin, I. V. Chem. Rev. 2011, 111, 6513-6556. doi:10.1021/cr200164y

52. Polindara-Garcia, L. A.; Montesinos-Miguel, D.; Vazquez, A. Org. Biomol. Chem. 2015, 13, 9065-9071. doi:10.1039/C5OB01170A

53. Hostetler, G.; Dunn, D.; McKenna, B. A.; Kopec, K.; Chatterjee, S. Chem. Biol. Drug Des. 2014, 83, 149-153. doi:10.1111/cbdd.12240

\section{License and Terms}

This is an Open Access article under the terms of the Creative Commons Attribution License

(http://creativecommons.org/licenses/by/4.0), which permits unrestricted use, distribution, and reproduction in any medium, provided the original work is properly cited.

The license is subject to the Beilstein Journal of Organic Chemistry terms and conditions:

(https://www.beilstein-journals.org/bjoc)

The definitive version of this article is the electronic one which can be found at: doi:10.3762/bjoc. 14.74 